\title{
Mapping Class and its Political Possibilities
}

\author{
Jane Wills \\ Department of Geography, Queen Mary, University of London, London, UK; \\ j.wills@qmul.ac.uk
}

The resurgence of interest in class that has been associated with the US-based working class studies agenda is very exciting. Scholars are finding new ways to explore the significance of class, and they are doing it as part of various political projects to celebrate working class lives and organisation (Russo and Linkon 2005). It is significant that these scholar-activists are finding ways to avoid hostilities between the "old" left and post-structuralism, consciously putting aside the battles that pit class against other forms of socio-cultural oppression. And perhaps most exciting from a geographical point of view, much of this new scholarship and activism has an acute sense of the importance of place.

Unlike sociology, cultural studies or social history, class never was one of the core issues or concerns of the geographical discipline. The discipline has never prioritised the question of class, and even though it came to prominence with the development of Marxist political economy from the 1970s onwards, class was largely taken for granted. Marxist geographers asserted the importance of class in the capitalist economy, and the working class as a political agent of change, but there was very little attention to the mechanics of class culture and organisation itself. The work developed by a number of geographers and sociologists working in the UK during the 1980s and known as the "localities projects" was an important corrective to this as it sought to ground studies of class in local economy, culture and politics (Bagguley et al 1990; Cooke 1986, 1989; Massey 1991). However, despite some excellent empirical and theoretical work, this approach largely ran out of steam.

It was not until the 1990s that a number of geographers began to develop two strands of work as an extension to this. On the one hand, geographers such as Andy Herod and Don Mitchell began to explore the agency of labour, the geography of trade unionism and its importance for understanding the production of space. In what 
became known as labour geography, researchers produced accounts of how workers organise, the difference that space and place make to that organisation, and the impact of labour on the very landscape of capitalism (early examples include Herod 1998, 2001; Martin, Sunley and Wills 1996; Mitchell 1996; Savage 1998; Tufts 1998). On the other hand, there was also something of a resurgence in studies of the geography of employment. Researchers looked at employment in export processing zones and global production chains, in new urban labour markets and in service sector employment (Allen and Henry 1997; McDowell 1997, 2003; Peck and Theodore 2001; Wright 2001). This work highlighted the intersection of employment and gender relations, the ways in which ethnicity and nationality impact upon work, and the importance of age/generation differences in labour market experience (Hanson and Pratt 1998; McDowell 1997, 2003, 2005, 2006; Raghuram and Kofman 2004). Moreover, important studies also illuminate the ways in which labour markets are regulated and new narratives of class are deployed (Haylett 2003; Peck 1996, 2001; Sunley, Martin and Nativel 2001).

Together, this work tells us much about contemporary geographies of employment and their implications for power relations between workers and their employers. Yet with hindsight, there are also important gaps in this work. Most obviously, it would be invaluable to draw together this work to create a more coherent story about the changing geography of employment, power relations and the politicisation of class. Yet in so doing, we would need more thought and research into the extraworkplace dimensions of class. Sociological research, in particular, has highlighted the role of popular discourse, media representations and state interventions in the reproduction of class (Skeggs 2000). A coherent geography of class would need to include this focus on class, culture and community alongside the more usual economic approach (and for moves in this direction, see McDowell 2006; Ward et al 2007). Moreover, it is an obvious weakness that the arguments about trade union geography only apply to the small percentage of the global working population that is collectively organised. At a time when the vast majority of workers have no influence over their terms and conditions of work, the political possibilities of class can only be understood by including the unorganised too.

Geographers could thus say more by taking a holistic approach to understanding the changing landscape of employment, its shifting power relations, the discursive reproduction and the political potential of class. Geographers are ideally placed to explore the spatialised relationships between economic investment, the labour process, community cultures, discourse, identity and politics. But to do so, we would need to avoid the banality of arguing that class processes are simply differentiated by place. We would need to connect the small scale to wider processes, and 
the particular to the general, in order to say more about the geographical conditions of work and their wider significance.

In practice, such geographical ambition would demand attention to at least four sets of concerns. The first would be to think carefully about our understandings of class. As yet, geographers haven't systematically engaged with the strengths and weaknesses of different definitions of class and how they might affect our ability to spatialise understandings of class. Mapping class will depend on whether we understand it as a matter of inequality, or power/status, or property ownership or surplus value production - or some combination of these. The political implications we draw from maps of employment, wealth and power will thus depend upon the way in which we interpret relations of class. As an example, if we understand class in terms of the ownership of the means of production, we would identify large numbers of proletarians in all parts of the world. There would be no a priori reason to distinguish nurses in London from nurses in the developing world, and indeed, many classical Marxists would argue that class relations have the same political implications wherever they are.

Yet if we define class in terms of the production of surplus value, and differentiate fundamental class relations from subsumed class relations (the latter being characterised as those who "sustain themselves by means of shares of extracted surplus labour distributed to them by one or another fundamental extracting class" (Resnick and Wolff 2006:94), the global map of class would look rather different. The growing numbers of workers in the global South who are engaged in fundamental class relations producing goods for markets in the global North would be shaded in one colour, and the growing numbers of workers in the global North who are engaged in subsumed class relations creating the conditions in which such production and other services are possible would be shaded in another. Indeed, if we follow Resnick and Wolff's (2006:96) definition, such subsumed classes would be further differentiated between those who direct "the social processes that are the conditions of existence for the capitalist fundamental class process" (which they call type 1 subsumed classes), including merchants, bankers, landlords, shareholders and supervisors, and those who are employed in support. This latter category (or type 2 subsumed classes) would include those funded by taxation, such as teachers, fire fighters, soldiers, police officers, nurses, carers and social workers alongside those paid from revenue generated elsewhere, such as cleaners, office staff, cashiers and maintenance workers. Drawing maps on this basis would highlight the uneven global geography of capital and labour relations.

Echoing the arguments made by labour geographers, these maps would highlight the importance of thinking geographically about the political potential of class. That said, however, we may produce yet more 
differentiated maps through analysis on the basis of the relative income from labour. Even if the labour process is geographically uniform, the direct and indirect income generated (via wages, the social wage and welfare provision, not to mention differentiated taxation and the cost of living) puts similar workers in very different economic positions in geographically divergent locations. Such differences are overlaid by nationally specific discourses and politicisations of class that further complicate the maps that we draw. At a time when there is a widening geographical gulf between the places where goods are produced and the markets in which they are consumed, there has never been a better time to produce a geographical analysis of the importance of class. Drawing such maps and exploring their implications, however, is far from straightforward.

Secondly, geography has real strength as a discipline for the study of intersectionality: to understand the ways in which class intersects with other social cleavages, with very different e/affects. There can be no essentialist analysis of class when taking a geographical view. But whereas feminist scholars have pioneered this kind of sophisticated geographical approach in relation to the study of gender, this has yet to be done from the perspective of class (and for work that focuses on the intersections of gender and class; see McDowell 1991; 2001; 2006). It would appear that there are particular ways in which class is intersecting with gender, ethnicity, nationality and generation in different parts of the world. Migrant labour, for instance, is of growing significance in the export processing zones of the developing world, just as it is increasingly important in the conurbations of the global North (see May et al 2007). Such intersections of class, ethnicity and nationality are often overlaid by gender relations as increasing numbers of women workers are moving across national borders. Understanding such intersectionality at the local level can help in mapping larger scale trends in the geography of class and employment (see Ong 2006).

Thirdly, as suggested above, any geography of class will have to include the study of socio-cultural economy. In addition to mapping employment and relations of class, a complete geography would have to attend to cultural representation, and popular and policy discourses about matters of class. In a country like Britain, class is the word that dare not speak its name behind the plethora of policy initiatives that are directed at geographically delimited communities requiring state intervention around issues like childcare (Surestart), poverty (New Deal for Communities), education (academies, action zones), employment (action zones, city challenge) and anti-social behaviour. Geography is often used as a surrogate for the question of class. The poor are increasingly identified by where they live, what they wear, what they eat and how they parent their children as much as where they actually work. Somehow, these developments would have to be connected to the 
wider changes in the spatial divisions of work (and for moves in this direction, see McDowell 2006).

Finally, there is scope for doing more to understand class and its politicisation. Whereas labour geographers have tended to study those workers who are already signed up to trade union organisations and may thus be mobilised to act around issues of class, there are more fundamental questions to be asked about the processes of politicisation itself. If class is a category that can be politicised, without any a priori assumptions as to how and why, it is critical to map the ways in which class can or can't become significant. Geographers are well placed to explore the circumstances in which class politics has proved possible, by what means and with what outcomes. In so doing, the map of class is simultaneously a map of class politics and political possibilities. Labour organisers are already developing more sophisticated maps of possibility, and geographers are well-placed to assist (see Anderson et al 2008).

Taking a coherent approach to mapping the global geography of class and its political possibilities represents an exciting academic project. It would allow us to demonstrate the importance of taking a geographical perspective to better understanding class, class politics and the political prospects of class.

\section{Acknowledgements}

Thanks to Linda McDowell, Alison Stenning, Tim Strangleman and everyone who helped to organise and/or attended the ESRC-funded Working Class Lives: Sociologies and Geographies seminar series from which these interventions arose. We also had a great audience at the Antipode-sponsored 2006 RGS-IBG conference session that explored the intersection of working class studies and geography. It has been wonderful to have the space for inter-disciplinary dialogue about matters of class.

\section{References}

Allen J and Henry N (1997) Ulrich Beck's risk society at work: Labour and employment in the contract service industries. Transactions of the Institute of British Geographers 22:180-196

Anderson J, Hamilton P and Wills J (2008) The multi-scalarity of trade union practice. In S McGrath-Champ, A Herod and A Rainnie (eds) Handbook of Employment and Society: Working Space. Cheltenham: Edward Elgar (forthcoming)

Bagguley P, Mark-Lawson J, Shapiro D, Urry J, Walby S and Warde A (1990) Restructuring: Place, Class and Gender. London: Sage

Cooke P (ed) (1986) Global Restructuring, Local Response. London: ESRC

Cooke P (ed) (1990) Localities: The changing face or urban Britain. London: Unwin Hyman

Hanson S and Pratt G (1998) Gender, Work and Space. London: Routledge

Haylett C (2003) Class, culture and urban policy: Reconsidering equality. Antipode 35:55-74

Herod A (ed) (1998) Organizing the Landscape: Geographical Perspectives on Labor Unionism. Minneapolis: University of Minnesota Press 
Herod A (2001) Labor Geographies: Workers and the Landscapes of Capitalism. London: Guilford

Martin R, Sunley P and Wills J (1996) Union Retreat and the Regions: The Shrinking Landscape of Organised Labour. London: Jessica Kingsley

Massey D (1991) The political place of locality studies. Environment and Planning A 23:267-281

May J, Wills J, Datta K, Evans Y, Herbert J and McIlwaine C (2007) Keeping London working: Global cities, the British state, and London's new migrant division of labour. Transactions of the Institute of British Geographers 32:151-167

McDowell L (1991) Life without father and Ford: The new gender order of post-Fordism. Transactions of the IBG 16:400-419

McDowell L (1997) Capital Culture: Gender at Work in the City. Oxford: Blackwell

McDowell L (2001) Father and Ford revisited: Gender, class and employment change in the new millennium. Transactions of the IBG 26:448-464

McDowell L (2003) Redundant Masculinities? Employment Change and White Working Class Youth. Oxford: Blackwell

McDowell L (2004) Work, workfare, work/life balance and an ethics of care. Progress in Human Geography 28(2):145-163

McDowell L (2005) Hard Labour: The Forgotten Voices of Latvian Migrant "volunteer" Workers. London: UCL Press

McDowell L (2006) Reconfigurations of gender and class relations: Class differences, class condescension and the changing place of class relations. Antipode 38:825-850

Mitchell D (1996) The Lie of the Land: Migrant Workers and the California Landscape. Minneapolis: University of Minnesota Press

Ong A (2006) Neoliberalism as Exception: Mutations in Citizenship and Sovereignty. Durham, NC: Duke University Press

Peck J (1996) Work-place: The Social Regulation of Labor Markets. London: Guilford Peck J (2001) Workfare States. New York: Guilford

Peck J and Theodore N (2001) Contingent Chicago: Restructuring the spaces of temporary labor. International Journal of Urban and Regional Research 25:471496

Raghuram P and Kofman E (2004) Out of Asia: Skilling, re-skilling and deskilling of female migrants. Women's Studies International Forum 27(4):95-100

Resnick S A and Wolff R (2006) New Departures in Marxian Theory: Economics as Social Theory. London: Routledge

Russo J and Linkon S (2005) (eds) New Working Class Studies. Ithaca: Cornell University ILR Press

Savage L (1986) Geographies of organizing: Justice for janitors in Los Angeles. In A Herod (ed) Organising the Landscape: Geographical Perspectives on Labor Unionism. Minneapolis: University of Minnesota Press

Skeggs B (2000) Class, Self, Culture. London: Routledge

Sunley P, Martin R and Nativel C (2001) Mapping the new deal: Disparities in the performance of welfare to work. Transactions of the IBG 26:484-512

Tufts S (1998) Community unionism in Canada and labor's (re)organization of space. Antipode 30:227-250

Ward K, Fagan C, McDowell L, Perrons D and Ray K (2007) Living and working in urban working class communities. Geoforum 38:312-325

Wright M (2001) A manifesto against femicide. In P Waterman and J Wills (eds) Place, Space and the New Labour Internationalisms (pp 227-245). Oxford: Blackwell 